\title{
Facing urban vulnerability through kampung development, case study of kampungs in surabaya, indonesia
}

\author{
Rita Ernawati $^{1, \text { * }}$, Happy Ratna Santosa ${ }^{2}$, Purwanita Setijanti ${ }^{2}$ \\ ${ }^{1}$ Department of Architecture, Intitute Technologi Sepuluh November, Surabaya, Indonesia \\ ${ }^{2}$ Department of Architecture, Intitute Technologi Sepuluh November, Surabaya, Indonesia
}

\section{Email address:}

myreeta80@yahoo.com(Rita Ernawati), happyratna@yahoo.com(Happy Ratna Santosa), psetijanti@yahoo.com(Purwanita Setijanti)

\section{To cite this article:}

Rita Ernawati, Happy Ratna Santosa, Purwanita Setijanti. Facing Urban Vulnerability through Kampung Development, Case Study of Kampungs in Surabaya. Indonesia. Humanities and Social Sciences. Vol. 1, No. 1, 2013, pp. 1-6. doi: 10.11648/j.hss.20130101.11

\begin{abstract}
Urban is a settlement area that has been untouched by the detailed planning, and be the largest population concentration where the human development done. Urban vulnerability is an indicator of high pressure to the city due to urbanization and globalization. Kampungs have become a key feature of cities in Indonesia. It is important to understand the role of kampungs in the urban development. Kampungs which are home to a large low-income people in general have environmental problems in lacking of basic service and infrastructure. Kampungs should be able to adapt in order to survive as a livable settlement. This paper will describe, how the kampungs (especially in Surabaya) can withstand the vulnerability of the city. The method applied in this paper is a qualitative descriptive study based on the literature and data compilation. The main data sources derived from statistical documents and the results of the study on the scope of the city of Surabaya. This paper is expected to provide a new paradigm, how the kampungs is able to survive in faceing the vulnerability of the city.
\end{abstract}

Keywords: Urban Vulnerability, Kampungs, Adaptation, Community Participation

\section{Introduction}

The population of Asia in 2030 is predicted reach 2.6 billion and more than $50 \%$ live in the city. These conditions provide a consequence to the vulnerability of the city because of limited resources to meet the needs of the entire population [1]. Urban centers are home to a large proportion of the world's population, economic activity, and physical infrastructures that are already at risk from floods, heat waves, droughts, and other hazards that climate change is expected to exacerbate.

Urban are the critical points of the largest social dislocation characterized by increased crime, severity of pollution problems, changes in demographic patterns, etc. Urban is also a settlement area that has been untouched by detailed planning, and be the largest population concentration where the human development occured. Indonesia is a hoterogen country; diversity includes numerous cultural groups and its cities reflect this diversity. Culture and environment condition was very influence in the urban development [2].

Indonesia recognize two patterns of development, namely the implementation of formal and informal type.
Formal development is done by middle and upper class with the ability to provide adequate capital. Meanwhile, low-income communities develop the informal systems. The pattern does not only happen in the economic sector, but also in the residential sector.

Housing system in Indonesia also a familiar pattern to formal and informal housing. Cities in Indonesia is dominated by informal settlements. Kampung is the word that commonly used for informal settlements [3]. In many big cities like Surabaya, kampungs become home of $70 \%$ inhabitants that built their own houses [4]. The ability of people to build their own housing shows great potential in solving the housing problem. As informal settlement, kampungs faceing big challenges in order to survive from the activities of formal development. The vulnerability of kampungs become crucial to be addressed so that the kampungs will not be eradicated such as in Jakarta where more than $20 \%$ of kampung disapear by eviction [5].

This paper will describe, how the kampungs (especially in Surabaya) can withstand the vulnerability of the city. The method used in this paper is a qualitative descriptive study based on the literature and data compilation. The main data sources are derived from statistical documents and the 
results of the study on the city of Surabaya. This paper is expected to provide a new paradigm, how the kampungs is able to survive in the face of the vulnerability of the city.

\section{Understanding Urban Vulnerability}

Vulnerability often associated with disasters, especially natural disasters. The term vulnerability has been a popular topic in scientific research in the decade. The concept has been used in different research, in spite of no concencus on its meaning [6],[7],[8]. Research on urban vulnerability is faced with tension between the need to represent differences within and across urban areas given by specific nature of the dimensions and factors involved, and the desire to identify determinants and attributes of adaptive capacity and resilience in the urban area [9].

The context of asset linkages and urban poverty defines vulnerability as insecurity, sensitivity of environmental change, related to the response and resilience of risk in the face of negative conditions [10]. Meanwhile, the physical and social issues in the urban concept defines vulnerability as critical situation due to physical and social problems in the urban development process [11].

Other scolars define vulnerability by system approach. Vulnerability is a function of the system's sensitivity and capacity to response, and the transformation suffered by the system is a function of its vulnerability, the properties of the perturbation, and the exposure of the system to the perturbation [8]. Figure 1 show, the proces of how time moves from top to bottom of the figure by Gallopin.

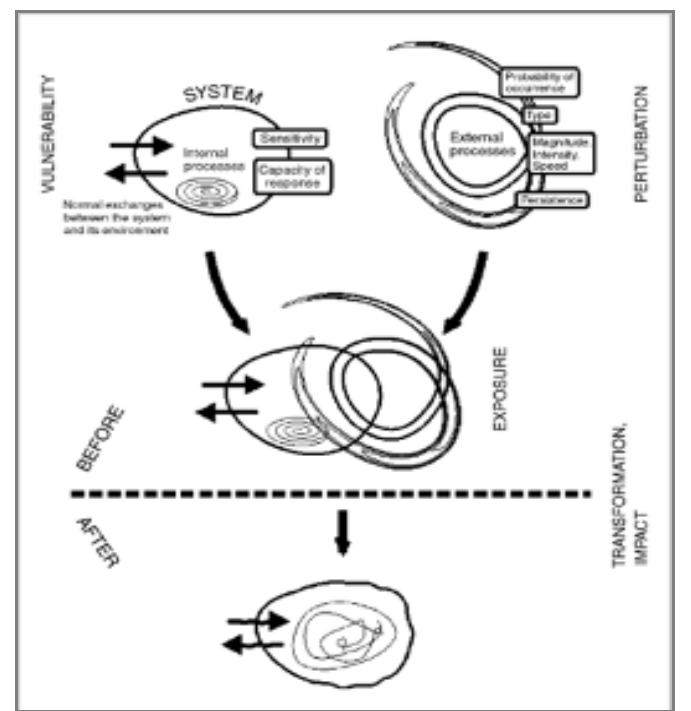

Figure 1. Generic relations between vulnerability, threat, exposure, and impact or transformation of a system

The target system is represented by an oval; its exchanges with its external environment are represented by arrows in both directions, and the normal operation of its internal processes is symbolized by a regular spiral. The components of the vulnerability of the system (its sensitivity and capacity of response) are highlighted with boxes. The considered (external) process or perturbation is represented by the looped shape at the right, with its relevant attributes in boxes. The exposure of the system to the perturbation is represented by the overlap between the two elements, and the transformed or impacted system is represented by the wobbly oval at the bottom.

Undestanding of urban vulnerability in general tend to portray it in negative terms, as the possibility to be harmed. The concept of vulnerability captures a complex and dynamic reality. Not only referring to the possibility about how a system is negatively affected by something, but also how to define both the sensitivity and the capacity to cope with that stressor. Vulnerability must be looked at as an interaction of these factors and includes several dimensions: impacts, exposure, sensitivity, capacity to adapt, and actual responses [9]. Figure 2 define a conceptual fremework of urban vulnerability in particulary to global climate and environmental change by Lanko and Qin.

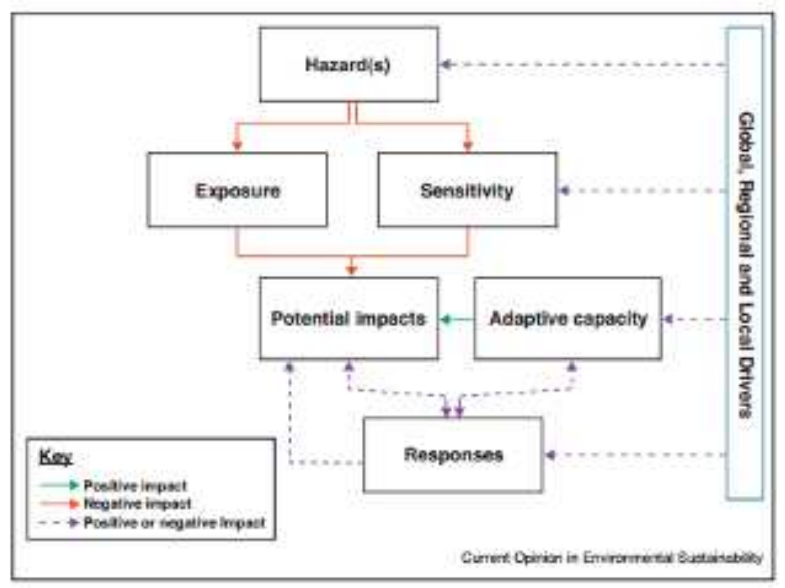

Figure 2. A conceptual fremework of urban vulnerability

In this paper, the discussion will focus on how the kampungs are able to respond and adapt to the vulnerability of the city. Vulnerability is not only seen as an impact, but also the challenges that must be faced by the kampung inhabitants.

\section{Urban Development in Indonesia}

Since the 1960s, economic growth in Indonesia is marked by major changes in the city center and the conversion of agricultural land into urban functions [12], [13]. The economic growth triggered the migration of villagers to the city. Informal settlemants started to emerge as shalter for unccounted urban inhabitants. Most government in developing contries regarded the mushrooming of informal settlements as a transitionary phenomenon that gradualy fade away with economic development [14], [15].

In Indonesia, informal settlements is not seen as a phenomenon but as part of entire community. Kampungs are informal, low cost housing that built through the 
traditional and informal process by the inhabitant. They grow incrementally through expansion and densification that are seen as basic building block. Kampungs are not percieved as squatter or slums settlements, although limitation of urban services facilities[16]. Kampung in Indonesia grows due to population migration, conditions were mostly slum village that reflects the poor economic conditions, the inability of local governments, and inadequate policies.

In 1980 approximately $85 \%$ of housing development in Indonesia is done by residents [17]. Kampung is a form of housing that was built by the residents. When compared with the formal settlements, the growth of kampungs are dominant in every region in Indonesia.

Lerry Ford have formulate a model of Indonesian cities with case in Jakarta (fig.3). He define a model of cities in Indonesia into nine zones: a port-colonial city zone, a Chinese commercial zone, an international commercial zone, a mixed commercial zone, a government zone, an elite residential zone, middle-income suburbs, industrial zones, and kampungs. Kampung as urban settlements demonstrate its existence since the colonial era to the present. Kampung as mostly unplanned, is primarily a low-income residential area that has gradually been built and serviced has covers most of the city. There are four-part typology of kampung: inner-city kampungs, midcity kampungs, rural kampungs, and temporary squatter kampungs [18].

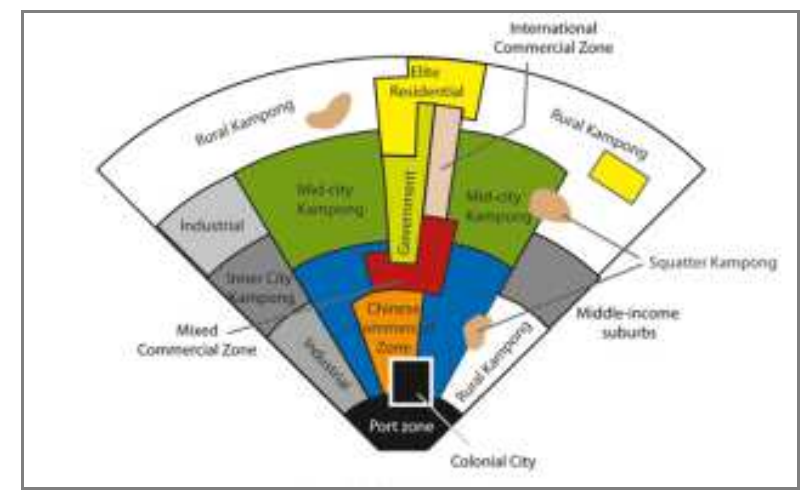

Figure 3. A model of Indonesian city structure

In terms of development and urban vulnerability, Jakarta is considered as one of the most vulnerable cities to climate-related disaster, including flooding, sea-level rise, and storm surge. The Jakarta City Government does not have concrete steps to tackle the problems. Current endeavors by the Jakarta City Government tend to focus more on disaster management, rather than efforts to specifically tackle the impact of climate change [19]. The rapid development of urbanization and demand led to a conflict of interest between economic growth and maintain villages (especially in the city center). The conflict occurred in Jakarta that resulted in many eviction of the kampungs. Significant decline in the proportion of villages in Jakarta which in the 1980 s reached $80 \%$ to $60 \%$ region in 2005 [5]. There is no balance between development and efforts to address the vulnerability of the city. In Jakarta kampung should be preserved in order to survive and face the ongoing challenges of times [20].

\subsection{Kampungs as Integral Part of Urban Development in Indonesia}

Urban development that is driven by the process of globalization needs to be controlled to protect the lower economic class. The increasing of urban population and urbanization were result of a proliferation feature of informal housing. Housing is a serious problem in both urban and rural areas in Indonesia. In the rural areas, housing generally falls below even the most modest standards. The main problem of housing in Indonesia is on quality not quantity [17].

It is important to understand the role of kampungs in the urban development. The existance of great number of kampungs show the limitation of the government to provide affordable housing for all. The inhabitants built informal housing in order to meet the basic needs independently [5]. The effort and ability of providing selp-help housing demonstrate the potential to solve the housing problems in Indonesia.

The existence of the kampungs as a space to foster economic activity needs to be maintained. In the process of urban development that will continue to happen, as kampungs still had a chance to give better meaning of urban life better and typical in Indonesia [21]. Many program have been conducting in order to improve the settlements condition. Kampung Improvement Program (KIP) was the first and successfull program that was recognized globally [1]. It was started in 1968 in order to ameliorate kampung with the upgrading of both physical and social infrastructure. This program become a model of community-led development particulary in Indonesia [22].

\section{The Kampung of Surabaya in Facing Urban Vulnerability}

\subsection{Surabaya in Brief}

Surabaya is Indonesia's second metropolitan city with a population of over 3.1 million, and the capital of East Java province [23]. It is located on the northern shore of eastern Java along the edge to Madura Strait. Surabaya is known as "the city of heroes" due to the importance of the Battle in galvanizing Indonesian independence and international support.

As the main seaport and commercial center in the eastern region of Indonesia, Surabaya has become one of the large cities in Southeast Asia. Transportation in Surabaya is supported by the infrastructure of land, sea and air transport that serve the local, regional, and international trip. Tanjung Perak is the main port of the city and is one of the busiest 
ports in the country. Nowadays, it is also one of the top ten busiest cargo ports in Southeast Asia. For air transport, the city is served by Juanda International Airport [24].

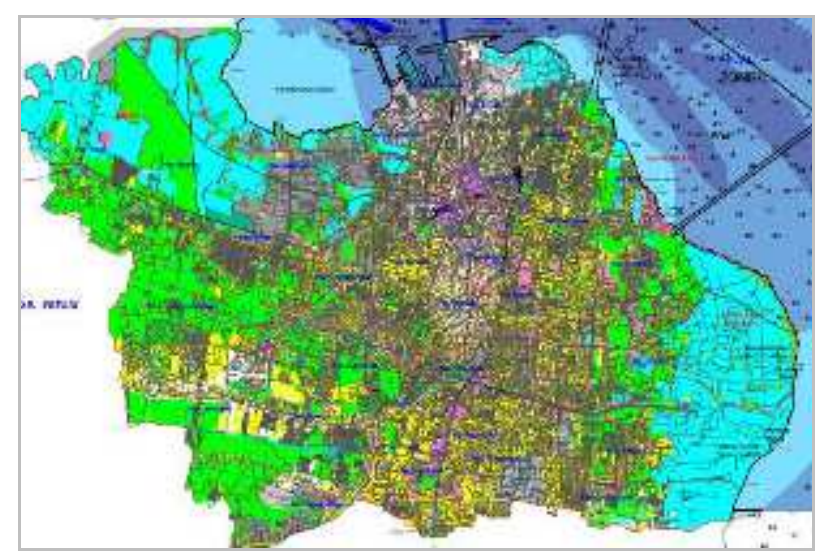

Figure 4. Map of Surabaya City

\subsection{The Kampung of Surabaya}

Kampungs are informal, low-income housing areas found throughout south-east Asia. They provide homes for 63 per cent of the population of Surabaya but cover only 7 per cent of the city area. Traditionally the kampungs contain a mix of socio-economic groups with low and middle-income households living alongside each other, although the majority of households are low-income [25].

As the center of economic development of east Indonesia, the comercial and office building growth in Surabaya are very high, especially in the city center. Site in the middle of the city become an attraction for investors to develop a range of business facilities. On the other hand, these conditions lead to vulnerability to the kampungs in the middle of the city to be able to compete with the market mechanism.

Kampungs in Surabaya as a home for most of the population continues to increase along with the growth of the city. They should be able to compete with other functions that provide better economic value. As well as settlements in major Indonesian cities, villages face many vulnerabilities, both physical and non-physical. Vulnerabilities threaten the existence of the village such as the insistence of city development needs, environmental degradation and social conflict.

Improving the quality of housing is the best strategy conducted by the city government to provide security for the community from the urban vulnerability. With the approach of community participation kampung improvement program is still implemented in Surabaya [26]. Participatory approach is a strategy for sustainable quality improvement program of the kampung by empowering local potential [27].

\subsection{KIP as Fundamental Approach to Urban Development in Surabaya}

The Kampung Improvement Programme originally started in the 1920 s by the Dutch Government with the aim to prevent the spread of disease from the kampungs to the neighbouring residential districts. Today's extensive KIP in Surabaya was started in 1968 and it has currently improved 70 per cent of the kampungs in the city [22]. Although such improvement programmes are taking place throughout Indonesia, those in Surabaya are unusual in the strength of the partnership that has developed between the low-income communities and the municipal authorities.

Improvement of the basic physical infrastructure of the kampung is the key element of KIP. The Kampung Improvement Programme in Surabaya provides a low-cost, innovative and sustainable method of transforming high-density urban informal settlements into green and clean neighbourhoods. Its success has been achieved by mobilising people's own resources and by increasing their awareness of the importance of a clean and healthy living environment.

The Surabaya Kampung Improvement Programme is a comprehensive neighbourhood programme which not only creates improved living conditions for low-income families but also, by involving the local community in the process, ensures its long-term sustainability and on-going improvement. The community is involved in the Kampung Improvement Programme from the very earliest stages. Preliminary surveys on the physical conditions in the Kampungs are carried out in co-operation with residents and the needs and problems of the community are discussed with them, providing the basis for future improvement plans [2].

Kampungs provide favourable conditions for starting any kind of informal business or home industry, since there are few overheads and many of the sites are centrally located. Wherever possible, residents are encouraged to set up their own small businesses.

\section{Urban Vulnerability through Kampung's Settlements in Surabaya}

Kampungs vulnerabilities is not only in economic aspect but also on the social and environmental aspects. That is because the diversity of the characteristics of the inhabitants and high building density. The condition was responded by the city stakeholder as a challenge for the village to improve their economic capacity to endure. Integrated approach by the government, is supported by the community in developing the potential of the village.

Kampungs inhabitants experience economic vulnerability related to its activities in the informal sector; small trade and home-based industries. The economy of the village community should be supported because it can create jobs independently. Kampungs economic development conduct through the development of the economic potential of each kampung in order to be more productive. Prominent kampung program is an effort to develop kampung economic activity esspecially on home-based industry through; training, provision of equipment and support broader marketing [28]. However, through creative 
innovations of the community with the support of the city government, the kampungs in Surabaya were able to transform to be green kampungs with green economic activity.

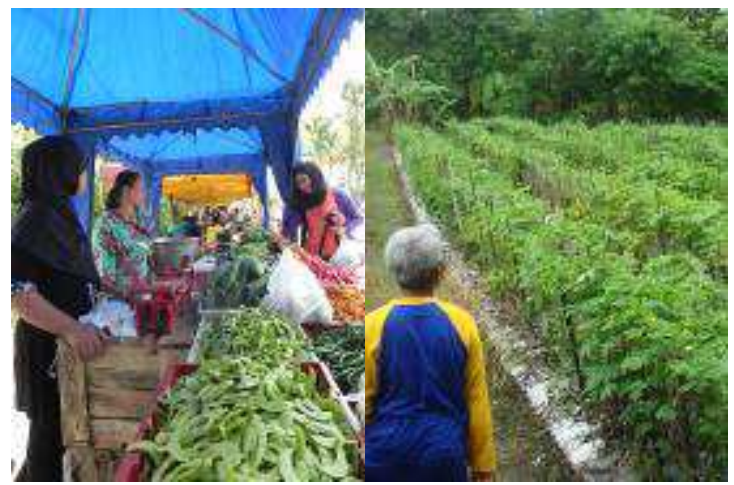

Figure 5. Urban Farming Integrated with the Market

Surabaya city lies on the coast of the Java Sea, and is highly vulnerable to flooding as it consist of sediment from two large rivers Bengawan Solo and Bratas and the process is still on going. A very rapid growth in the 1980 's resulted in the high intensity of the building (especially in the city) and the decline in the quality of urban environment.

Environmental degradation have an impact on the vulnerability of urban environment; increased pollution and flooding. The city government initiated a quality environments improvement with the development of green space, community-based environmental management, through the involvement of all stakeholders in the city. Restoring the function of land previously used for commercial activities to be green space can improve the quality of the city both physically and socially. Green open space is also developed to provide an alternative recreational facilities for the community especially in the kampungs [29].

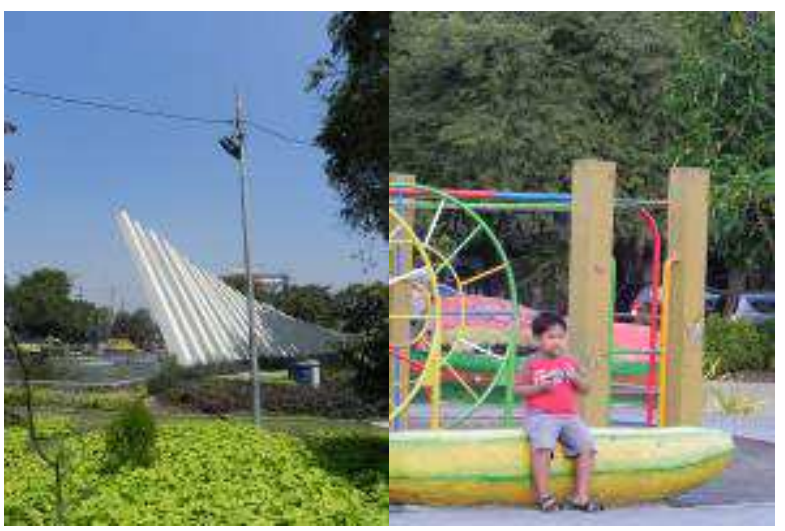

Figure 6. Green Space for the Community

Initiation of community-based environmental management program through green and clean, and free of litter. Both programs were able to increase public awareness of the importance in protecting the environment.

Surabaya is success in providing solutions in the provision of decent housing through the development of the village, so as to improve the quality of life is sustainable and internationally recognized. Building and Social Housing Foundation (BSHF) in the UK in 1992 has provided an appreciation of Surabaya and Singapore for the success of sustainable settlements [30].

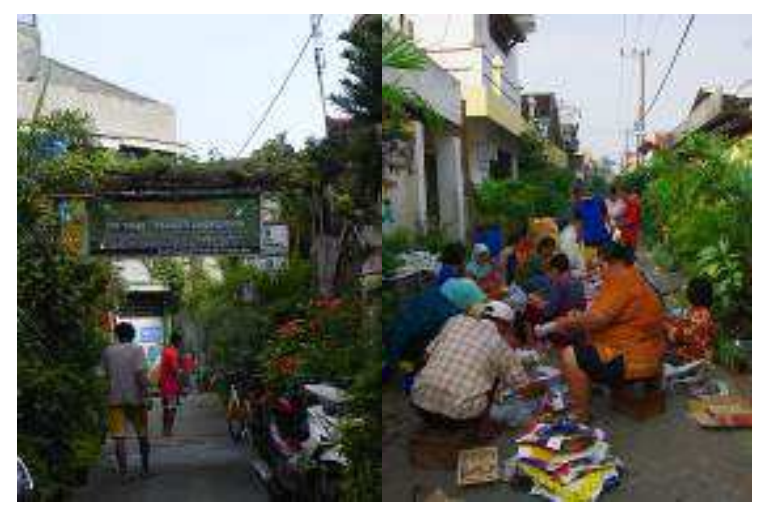

Figure 7. Community Participation of Kampung Inhabitants

Good living condition propose good quality of life for the community. The effort of inhabitants for creating livable settlements have to be improve in order to sustaining the kampungs.

\section{Conclusion}

The experience of Surabaya in developing kampung as fundamental aspect in urban development made Surabaya a city that were able to create a society that is active and making the city development beyond the prevailing standards of town and cities in Indonesia and simultaneously encouraging the citizens to act as the winner and creating a civilized living condition. It is also important to note that the achievements of Surabaya were reached through the continuous effort by the local government, involving as much as many stakeholders. Thus the experience in this respect not unique and can easily be adopted and implemented in other cities and towns. Surabaya city has many challenges, and an opportunity to realize an ecological city in accordance with local conditions.

Family or community level effort (e.g. self-help housing) is seen as a fundamental mechanism to allow individuals and households to cope with the hazards they constantly encounter. Good cooperation between the community, city government and all other city stakeholders in improving the environmental quality of the village is the key to realize sustainability for the next generation.

\section{References}

[1] UNHABITAT, Sustainable Urbanization in Asia, A Source Book for Local Government, United Nations Human Settlements Programe, 2012

[2] Wahid, A. Pemenuhan Secara Terpadu: Sebuah Pandangan Tentang Wawasannya Bagi Permukiman di Perkotaan. dalam 
Budiharjo, E. (Ed). 2009. Perumahan dan Permukiman di Indonesia. Penerbit: PT. Alumni, Bandung, 1983.

[3] Budiarto, L., Dwellers and Stranger: Socio-culture entity, space-use, and spatial configuration in kampung settlements of Jakarta, Indonesia, Proceeding-4th International Space Syntax Symposium, London, 2003.

[4] Silas, J. The Kampung improvement Programme of Indonesia: A Comparative Case Study of Jakarta and Surabaya, dalam Payne, G.K (ed) Low-income Housing in the Developing World, John Wiley \& Sons Ltd, 1984.

[5] Budiarto, L., Magersari: The Spatial Culture of Kampung Settlements as An Urban Strategy in Indonesian Cities and Urban Housing, SPACELAB, Faculty of Architecture Delft University of Technology, Delft, The Netherland, 2005.

[6] Adger, W.N., Vulnerability. Global Environmental Change 16 (3), pp. 268-281, 2006.

[7] Smit, B., Wandel, J., Adaptation, adaptive capacity and vulnerability. Global Environmental Change 16 (3), 282-292, 2006.

[8] Gallopin, G.C., Lingkage between Vulnerability, Resilience, and Adaptative Capacity, Global Environmental Change, Elsevier, 16: 293-303, 2006.

[9] Lankao, P.R and Qin, H., Conceptualizing Urban Vulnerability to Global Climate and Environmental Change, Environmental Sustainability, Elsevier B.V., 3:142-149, 2011.

[10] Moser,C.O.N, The Asset Vulnerability Framework: Reassessing Urban Poverty Reduction Strategies, World Development Vol. 26 No. 1, Elsevier Science Ltd, pp.

[11] Lopez, P.K., Three Approaches to Urban Vulnerability: Social, Physical and Urban. Vulnerable Areas in the Interior of A Chilean City, Urban Department of ETSAM, Universidad Politecnica de Madrid

[12] McGee, .T.G. The emergence of desakota region in Asia: expanding a hypothesis, in N. Ginsburg, B. Koppel and T.G. McGee (Eds) The Extended Metropolis Settlements Transition in Asia, Honolulu: University of Hawai Press, pp. 3-25, 1991.

[13] Zhu. J., Symetric Development of Informal Settlements and Gate Communities: Capacity of State Th Case of Jakarta Indonesia, Asia Research Institute, National University of Singapore, 2010.

[14] Hardoy, J.E. and Satterthwaite, D. Squatter Cities, Earthscan Publication Ltd, London, UK, 1989.

[15] Takahashi, K. Evolution of the Housing Development Paradigmes for the Urban Poor: The Post-war Shouteast Asian Context, Journal of Asia-Pacific Studies, Waseda University, No. 13, October 2009.
[16] Silas, J., "Government - community partnerships in Kampung improvement programmes in Surabaya", Environment and Urbanization, vol. 4, No. 2, 1992.

[17] Struyk, Hoffman and Katsura,The Market for Shelter in Indonesian Cities, The Urban Institute Press, Washington, D.C., 1990.

[18] Ford,L.R A Model of Indonesian City Structure, Geographical Review, Vol. 83, No. 4. (Oct., 1993), pp. 374-396, 1993.

[19] Firman, T., et.al, Potential Climate-change Related Vulnerability in Jakarta: Challanges and Current Statuse, Habitat International, Elsevier Ltd, 35: 372-378, 2010.

[20] Juwono, S. Keberadaan Kampung Kota si Kawasan Segitiga Emas Kuningan Kontribusi pada Rancang Kota, Proceeding Seminar Nasional PESAT, Universitas Gunadarma, Jakarta Agustus 2005.

[21] Setyawan, B. Kampung Kota dan Kota Kampung: Tantangan Perencanaan Kota di Indonesia, Universitas Gajah Mada, Yogyakarta, 2010.

[22] Silas, J. KIP (Kampung Improvement Program) in Surabaya, in D'Auria, V. et.al. (Eds) Human Settlements Formulation and (re) Caliberation, Author and SUN Architecture Publisher, Amsterdam, 2010.

[23] BPS, Surabaya dalam Angka Tahun 2011, Surabaya City Government, 2010.

[24] Bappeko, Draft RTRW Kota Surabaya, Surabaya City Government, 2012.

[25] Municipal Government of Surabaya and Laboratory for Housing and Human Settlements ITS, Surabyaa a city of Partnership to year 2000, 1992.

[26] Setijanti,P. Sustainable Concept and Approach in Improvement of Lives for Slum Dwellers: Surabaya's Practices, Journal of Architecture and Environment Volume 8, No 2, pp. 92-111, October 2009 (92-111)

[27] Dhakal, S., Comprehensive Kampung Improvement Program in Surabaya as a Model of Community Participation, Working Paper Urban Environment Management Project, Institute for Global Environmental Strategies (IGES), December 2002, Kitakyushu, Japan, 2002.

[28] Silas, J. et.al. Kampung Surabaya Menuju Abad XXI, Bappeko Surabaya, 2012.

[29] UCLG Committe on Social Inclusion, Participatory Democracy and Human Rights. Surabaya, Indonesia: Green and clean initiative, www.uclg.org/cisdp/observatory, 2012

[30] BSHF Cities of the Future: Successful Housing Solutions in Singapore and Surabaya. Building and Social Housing Foundation, Unaited Kingdom, 1993. 